\title{
New citations to the agaricobiota (Fungi - Basidiomycota) in oak forests of the Northeastern Andes of Colombia
}

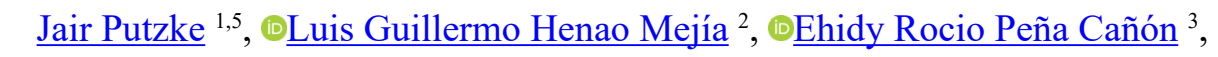 \\ (i) Yeina Milena Niño Fernández ${ }^{3}$ and $₫$ Teodoro Chivatá Bedoya ${ }^{4}$
}

Received: 14 March 2019; accepted: 11 December 2019

How to cite: Putzke, J., Mejía, L.G.H., Cañon, E.R.P., Fernández, Y.M.N. \& Bedoya, T.C. New citations to the agaricobiota (Fungi: Basidiomycota) in oak forests of the Northeastern Andes of Colombia. Hoehnea 47: 422019. http://dx.doi.org/10.1590/2236-8906-42/2019.of Colombia. Hoehnea 47: 422019. http://dx.doi.org/10.1590/2236-890642/2019. e first report of apomixis. Hoehnea 47: e212019. http://dx.doi.org/10.1590/2236-8906-21/2019.

ABSTRACT - (New citations to the agaricobiota (Fungi - Basidiomycota) in oak forests of the Northeastern Andes of Colombia). The study of Colombian agaricobiota is relatively recent. The training of new researchers has allowed more taxonomic surveys, increasing the literature on the subject and indicating the relevance of ecological and conservation studies. During a field survey conducted in the oak forests (Quercus humboldtii) in the Madre Monte Nature Reserve, municipality of Arcabuco - Colombia, in October 2018, about 40 specimens of Agaricales mushrooms were collected. The species were identified following the usual methods in Agaricology of the Laboratorio del Grupo de Investigación Biología para la Conservación de la Universidad Pedagogica y Tecnológica de Colombia. We identified a few species: Campanella elongatispora Singer, Cheimonophyllum candidissimum (Berk. and Curt.) Singer, Marasmiellus bolivarianus Singer, and Pluteus chrysophlebius (Berk. and Curt.) Sacc., which were added as new citations to Colombia. An increase in the area of occurrence of certain species of Agaricales-mushrooms was also reported.

Keywords: Agaricales, fungi, mycogeography, taxonomy

RESUMEN - (Nuevas citas de la agaricobiota (Fungi - Basidiomycota) em bosques de roble de los Andes del Noroeste de Colombia). El estudio de la agaricobiota colombiana es relativamente reciente; la formación de nuevos investigadores ha permitido más levantamientos taxonómicos, aumentando la bibliografía sobre el tema y posibilitando la realización de estudios ecológicos y de conservación. En una salida a campo realizada a robledales (Quercus humboldtii) en la Reserva Natural Madre Monte, Municipio de Arcabuco - Colombia, en Octubre de 2018, fueron encontrados cerca de 40 especímenes de hongos Agaricales. Las colectas fueron identificadas por los métodos usuales en micología en el Laboratorio del Grupo de Investigación Biología para la Conservación de la Universidad Pedagogica y Tecnológica de Colombia. Del material estudiado se reportan nuevos registros de especies para el país y se aumentó el área de ocurrencia para otras especies. Campanella elongatispora Singer, Cheimonophyllum candidissimum (Berk. y Curt.) Singer, Marasmiellus bolivarianus Singer y Pluteus chrysophlebius (Berk. y Curt.) Sacc. son referencias nuevas para Colombia.

Palabras clave: Agaricales, hongos, micogeografia, taxonomía

\section{Introduction}

The first records of Agaricales fungi of Colombia were published by Chardon (1928), which detailed the research investigations carried out in the country. The most current reports indicate that there are at least 1239 species of macrofungi registered, of which 1058 are Basidiomycota; and 537 of these are Agaricales (plus 63 of Russulales); these are reported in 130 publications in Colombia alone (Vasco-Palácios \& Franco-Molano 2013).

Paleoecological (Palynology) testimonies on the presence of the only species of oak (Quercus humboldtii) in Colombia dates to 450,000 years ago; these trees are found in the mountains around of the savanna of Bogotá. The authors of one of the most

\footnotetext{
Universidade Federal do Pampa, Campus São Gabriel, Av. Antonio Trilha, 1847, 97300-162 São Gabriel, RS, Brasil Fundación Inguedé para la Conseravion del Trópico, Aparato Aéreo 41595, 110311 Santa Fé de Bogotá, Colombia Grupo de Investigación Biología para la Conservación, Escuela de Ciencias Biológicas, Facultad de Ciencias Básicas, Universidad Pedagógica y Tecnológica de Colombia, Avenida Central del Norte 39-115, Tunja, 150003 Boyacá, Colombia Instituto Politécnico Industrial de Telecomunicaciones, Carrera 20 numero 20-25 El Yopal, 850001 Casanare, Colombia Corresponding author: irputzkebr@yahoo.com
} 
recent books on oaks in Colombia asked: "how do I understand the vigor and aggressiveness of the oak to have colonized much of our mountain slopes, especially the internal ones that look towards the valleys of Magdalena and Cauca rivers?" (Rangel 2017). We believe the association with mycorrhizae and other fungi could be the answer.

Most of the research studying fungi of Quercus humboldtii forests began in the last century, mainly by Singer, (1963, 1970a, 1970b, 1976), Dennis (1970), Pineda et al., (1988), Velásquez et al., (1988), Halling (1989), Horak \& Halling (1991), Guzmán (1983), Franco-Molano et al., (2000), Montoya et al., (2005), López-Quintero et al. (2007), Peña \& Enao (2014) and others. Even though several works have focused on the mycorrhizal mushrooms, little is known about their relationship with other species. The ethnomycethological knowledge is increasing and is centered mainly between the peasant communities and indigenous people of Colombia (Henao \& Ruiz 2006). No recent work on the taxonomy of saprophytic fungi in the oak forest is available.

The actual number of species of Agaricales fungi associated with oak forests is still far from a final number and this work aims to contribute to these studies. The proposed work aimed to better understand the Agaricales species composition in the Quercus humboldtii forest in the Colombian Andes.

\section{Materials and methods}

A survey on the Quercus humboldtii forest was conducted in October 2018 to verify the occurrence of Agaricales fungi. The sampling of Agaricales mushrooms was carried out in the Natural Reserve of Madre Monte, municipality of Arcabuco, Boyacá Department - Colombian Andes. Through the technique of transects (20 m long) we studied the occurrence of mushrooms in four forest areas. The species were identified through the usual techniques in agaricology and carried out in the laboratory of the Conservation Biology Investigation Group in the School of Biological Sciences in the Pedagogical and Technological University of Colombia (UPTC). Descriptions of each species found were done using authors' observations on macro and microstructures. Samples were dried out at $40{ }^{\circ} \mathrm{C}$ and were deposited in the UPTC Herbarium.

\section{Results and Discussion}

The samples collected were identified and their respective species are described below, indicating their structures and range of occurrence.

Campanella aeruginea Singer, Hedwigia 26 (4): 854. 1976.

Figure 1

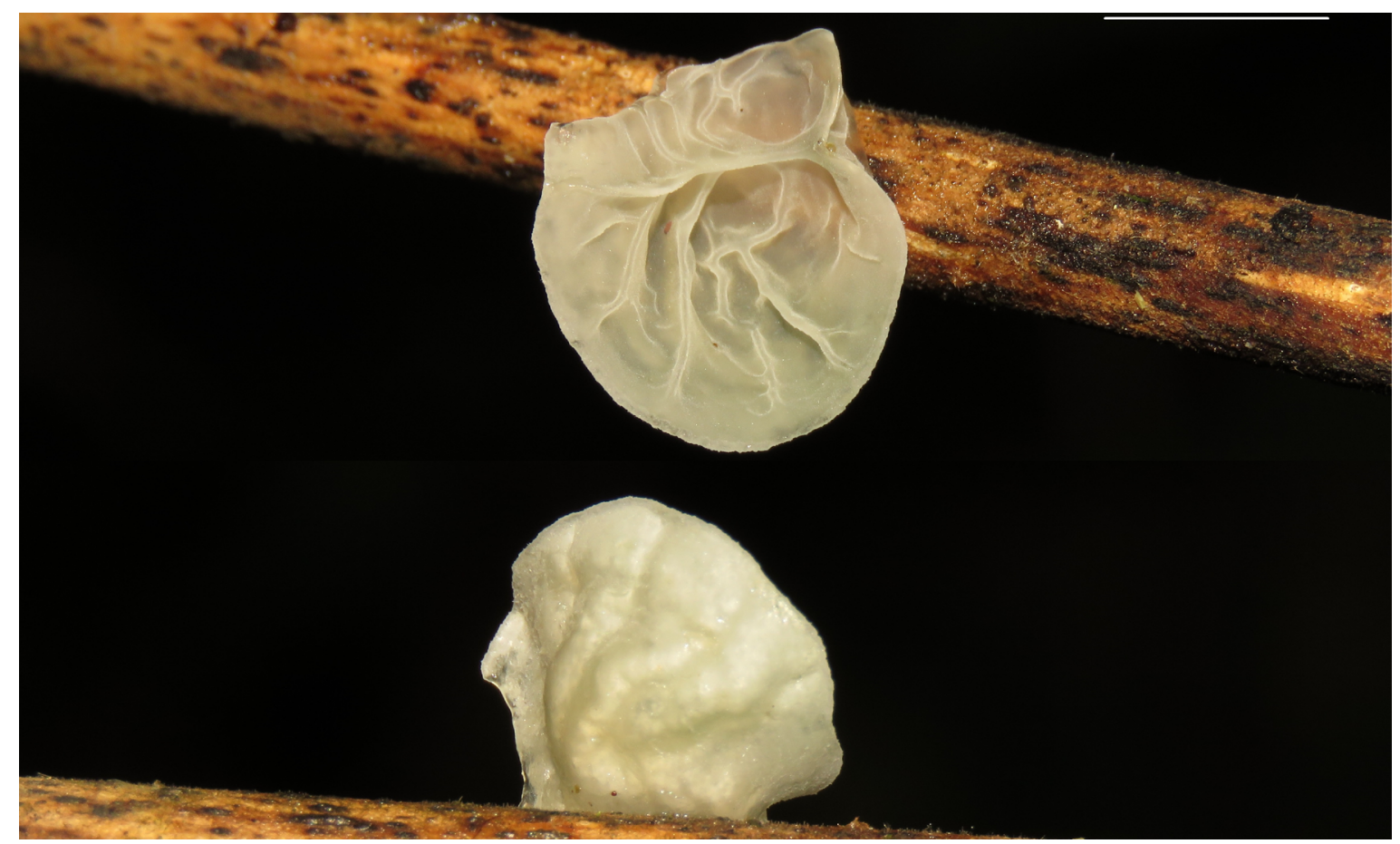

Figure 1. Basidiome of Campanella aeruginea Singer $($ Scale $=5 \mathrm{~mm})$. 
A white pileus up to $10 \mathrm{~mm}$ in diameter, that changes to bluish-green with age, irregularly trabeculated, and sessile. The hymenophore has seven lamellae which are irregularly intervenose and have the same color as the pileus surface. Spores were $6.5-8 \times 3.7-4.2 \mu \mathrm{m}$, ellipsoid to pip-shaped, inamyloid, thin-walled and hyaline. Basidia were 30-45 $\times 8-10 \mu \mathrm{m}$, tetraspored. Pleurocystidia were similar to basidia. Cheilocystidia were 40-65 × 4.8-9.6 $\mu \mathrm{m}$, hyphalic, digitate, undulate, lobed or divaricate, thick-walled but not metuloidal. The context was formed by thin hyphae immersed in a gelatinous mass. Cortical layers of pileus composed of densely ramified irregularly undulate and lobed hyphae and few pileocystidia projecting up to $40 \mu \mathrm{m}$, which change to asterophyses when mature and immersed in a gelatinous mass. Often found on dead bamboo stalks.

The pileus is white but, in some regions, changes to bluish-green color, with age and the hymenium forming the characteristic cheilocystidia, are distinct features of this species. There are at least other five species were the basidiomata changes to bluish or greenish with age. Farook and Manimohan (2014) consider Campanella aeruginea as South American and having ampullaceous cheilocystidia, smaller basidiospores and monocotyledonous hosts, compared to C. keralensis V.A. Farook \& Manim., described from India. Campanella aberrans Singer is differentiated because it has no thick-walled cystidia and smaller spores (Singer 1975). Campanella caesia Romagn. has cheilocystidia with a diverticulate lower part and no pleurocystidia (Singer \& Hausknecht 1990). Campanella tristis (G. Stev.) Segedin has a lateral or eccentric stipe and no pleurocystidia (Segedin 1993). C. eberhardtii (Pat.) Singer is also found growing on monocotyledoneous host in Vietnam and has broadly fusoid, conical or subcylindric cheilocystidia with rounded blunt tips (Parmasto 1981).

Campanella aeruginea is one of the missing type specimens of the historical collection of Rolf Singer maintained in Tucumán - Argentina, so it is important to recollect authentic material to designate lecto and neotypes (Perera et al. 2017).

This is the first report of this species in the Boyacá Department, being cited earlier to Cundinamarca and Chocó departments in Colombia.

Material examined: COLOMBIA. Boyacá Department, Arcabuco, Reserve of Madre Monte, J. Putzke et al., 13-X-2018, UPTC (0001).
Campanella elongatispora Singer, Nova Hedwigia 26 (4): 851. 1975.

Figure 2

The white pileus was 5-8 $\mathrm{mm}$ in diameter, in the form of convex fans to subaplanate, sessile, glabrous to villose under the magnifying glass and marked with venations for the transparency of the hymenophore.

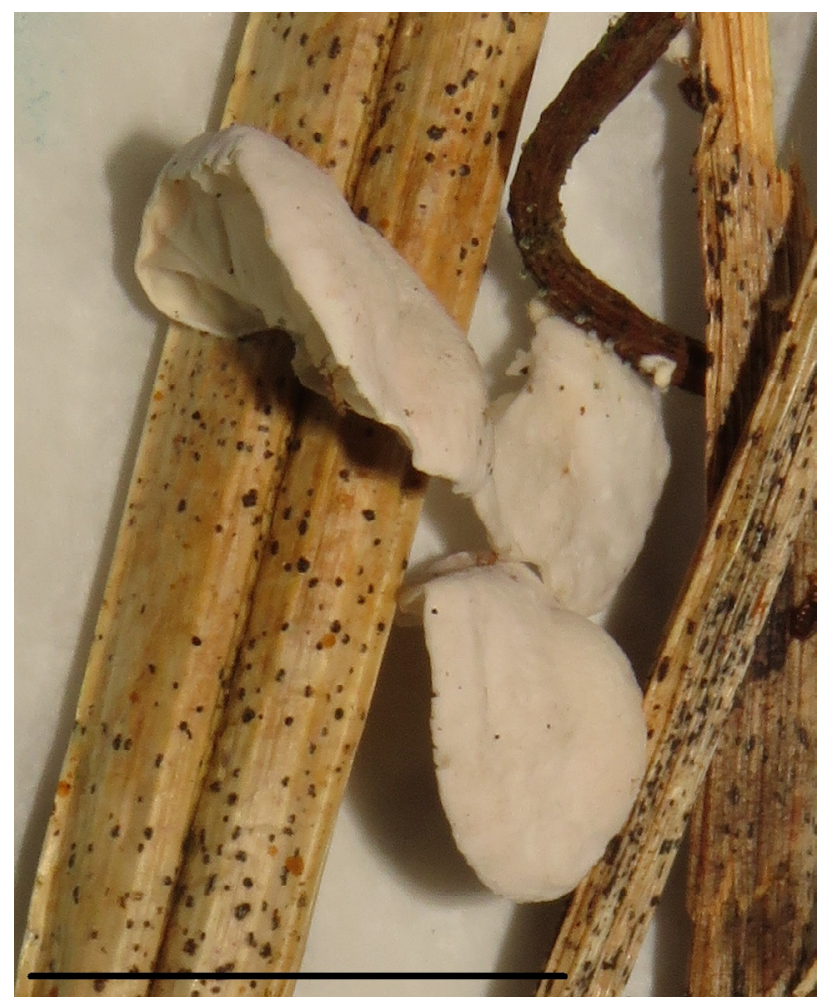

Figure 2. Basidiome of Campanella elongatispora Singer (Scale $=10 \mathrm{~mm}$ ).

Lamellae were white with transverse venations. The context was white, subgelatinous, thin, up to $1 \mathrm{~mm}$ thick. Spores were 8.8-12 × 3-4 $\mu \mathrm{m}$, elliptical-fusoid to pyriform, with a small hilar appendage, hyaline, with a thin and smooth wall. Basida were $25-35 \times$ $7-10 \mu \mathrm{m}$, tetraspored. Pleurocystidia were $28-56 \times$ 4.5-9 $\mu \mathrm{m}$, lageniform to capitate, with a wide lower part, tapering towards the apex which is capitated, and hyaline. Cheilocystidia were similar to pleurocystidia. Cortical layers of the pileus with hyphae showing 2-5 $\mu \mathrm{m}$ in diameter, subparallel to the surface, hyaline to pale gray, shortly septate and with some diverticula in the terminal cells. Hyphae of the context were 2.5-3.2 $\mu \mathrm{m}$ in diameter, hyaline, with a subparallel to an irregular labyrinthiform arrangement, with abundant clamp connections. Gregarious, on fallen branches inside the forest. 
The white pileus does not changes to yellow or orange colors when it is old, reticulate to lamellate hymenophore, spores dimensions and form, pleuroand cheilocystidia capitate with a long neck are characteristic for this species, which often grows on bamboo. Neocampanella blastanos (Boidin \& Gilles) Nakasone, Hibbett \& Goranova, has a thin, effuse, white to yellow or orange basidiome with capitate cystidia, dendrohyphidia and pyriform basidiospores, growing on hardwood, and very similar to the holotype of $C$. elongatispora Singer according to Nakasone et al., (2009). However, this species has no yellow or orange tinges. C. agaricina (Mont.) Lloyd is distinguished by a yellowish to orange pileus and larger spores (Putzke 2002).

The species was originally described from Ecuador (Singer 1975) and later also reported in Mexico (Chacon 1995) and Southern Brazil (Putzke, 2002), and is distributed throughout Central and South America.

This is the first citation of Campanella elongatispora in Colombia.

Material examined: COLOMBIA. Boyacá Department, Arcabuco, Reserve of Madre Monte, J. Putzke et al., 13-X-2018, UPTC (0002).
Cheimonophyllum candidissimum (Berk. \& Curt.)

Singer, Sydowia 9: 418. 1955.

Figure 3

The pure white pileus was $2-7(-10) \mathrm{mm}$ in diameter, convex, reniform or irregularly lobed, minutely velvety, glabrescent, and smooth. Lamellae radiating from a lateral attachment point, were white, somewhat broad, subdistant, with lamellulae of two sizes. The lateral stipe was rudimentary or absent, solid, with white, pruinous surface attached to basal mycelium near the substrate. Spores were 5.0-6.5 $\times$ 4.5-5.5 $\mu \mathrm{m}$, subglobose, hyaline, inamyloid, smooth, and thin-walled. Basidia were 23-30 $\mu \mathrm{m}$, tetraspored. Pleurocystidia were absent. The lamellae border was sterile, with abundant cheilocystidia, which are filiform, 40-60 × 3-6 $\mu \mathrm{m}$, hyaline, thin-walled, with a pointed apex and base that was somewhat inflated, and an almost regular hymenophore, formed by hyaline hyphae 1.5-2.5 $\mu \mathrm{m}$ in diameter. It had a welldeveloped subhymenial layer with interwoven hyphae of up to $10 \mu \mathrm{m}$ in diameter. The cortical layer of the pileus was formed by a trichoderm, with hyphae 30$70 \mu \mathrm{m}$ in length. White, thin, non-gelatinized context, formed by narrow, slightly inflated hyphae, 1.5-3 $\mu \mathrm{m}$

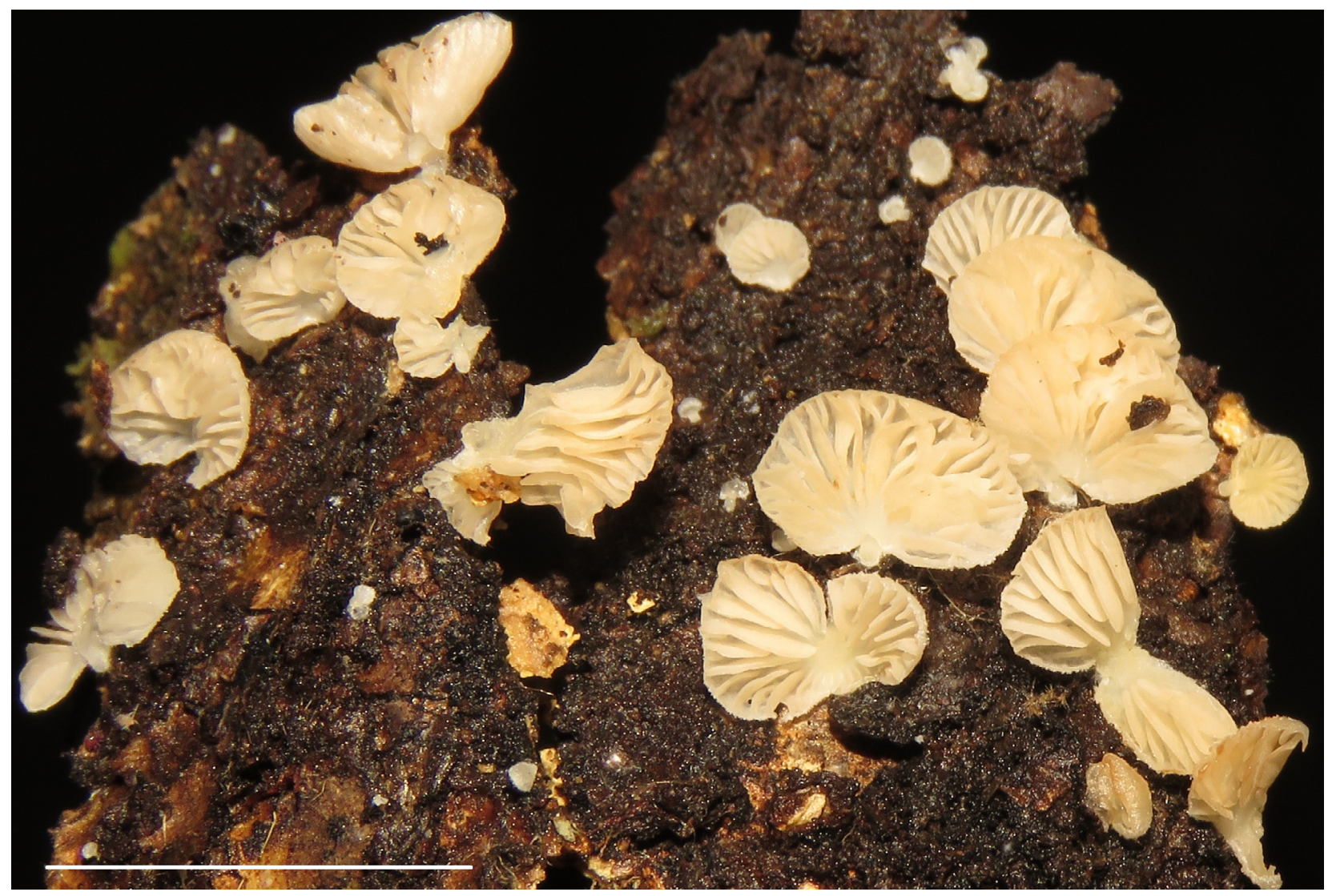

Figure 3. Basidiome of Cheimonophyllum candidissimum (Berk. \& Curt.) Singer (Scale = $10 \mathrm{~mm}$ ). 
in diameter, with slightly thickened walls and with clamp connections.

Grows on dead wood, the cortex and on small branches inside forests. It is interesting that the species grows frequently on the first $50 \mathrm{~cm}$ of trunks near the soil.

There are no difficulties in differentiating this species from others. The species found in the tree cortex has an appearance of Crepidotus but with very long and completely hyaline spores (white spore print). By habit, it can be confused with Marasmiellus, from which it differs by the cortical layer. Pegler (1983) has recorded this species in the USA, Cuba and the Antilles. Dennis (1986) cites it being present in Europe, South and North America. Putzke (2002) cites for being present in southern Brazil.

Material examined: COLOMBIA. Boyacá Department, Arcabuco, Reserve of Madre Monte, J. Putzke et al., 13-X-2018, UPTC (0003).

Laccaria fraterna (Cooke \& Mass. ex Sacc.) Pegler, Australian Journal of Botany 13(2): 332. 1965. Figure 4

The pileus was $15-45 \mathrm{~mm}$ in diameter, planeconvex at maturity, depressed in the center or with a small umbo (not often), reddish-brown towards the center, reddish-orange to orange-yellow at the margin, dry with striations sometimes sulcate at the margin. Lamellae were adnate with a decurrent tooth, pinkish to coral pink, with a distant, even margin. The stipe was $30-60 \times 2-5 \mathrm{~mm}$, with equal or slight thickening towards the apex, central, cylindrical, hollow, reddish-brown, fibrous, with small white floccules at the junction with the pileus. The context was reddish-orange, and thin. The spore print was white. Spores were $8-9(-10) \times$ 7-9 $\mu \mathrm{m}$, subglobose to globose, hyaline, with walls up to $1 \mu \mathrm{m}$ thick, with spines 1-1.5 $\mu \mathrm{m}$ long, and inamyloid. Basidia were 41-50 × 7-10 $\mu \mathrm{m}$, bispored. Pleurocystidia and cheilocystidia were not seen. The hymenophore had a regular trama. The pileipellis was a cutis of repent hyphae, 5.5-13 $\mu \mathrm{m}$ in diameter, and thin-walled. Clamp-connections were not seen.

This species is mycorrhizal to Eucalyptus spp. which grows in the area. The typically bispored basidia, and subglobose spiny and hyaline spores are distinctive. Among the species of this genus found in Colombia, Laccaria amethystina Cooke (with globose spores) and L. gomezii Singer and G. M. Muell. (subglobose to ellipsoid spores) have a pileus and lamellae that were purple to amethystine
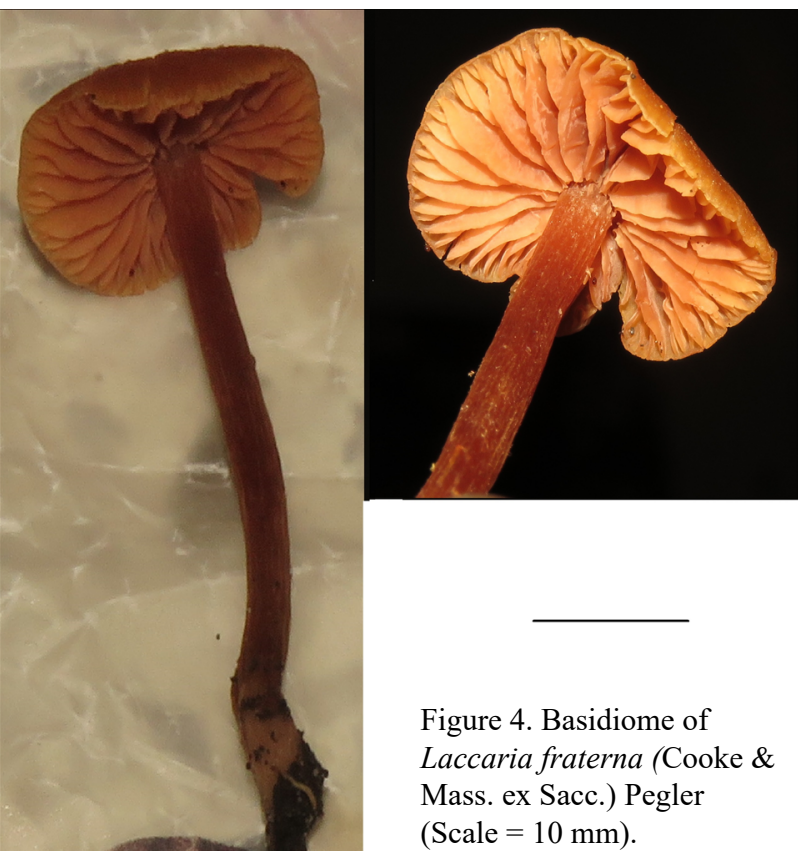

colored. Laccaria proxima (Boud.) Pat. and Laccaria laccata (Scop.) Cooke are found in Pinus plantations. Laccaria ohiensis is similar but has a four spored basidia. Even though some authors reported it to have bispored basidia, Mueller and Vellinga (1986) and Mueller (1992) found that the type specimen of L. ohiensis possess exclusively tetraspored basidia. Laccaria lateritia Malençon also has bispored basidia and occurs in Eucalyptus plantation and is considered a synonym of Laccaria fraterna.

This is the first report of this species in Boyacá (despite another collection with unpublished data) and is already cited in the Cundinamarca Department.

Material examined: COLOMBIA. Boyacá Department, Arcabuco, Reserve of Madre Monte, J. Putzke et al., 13-X/-018, UPTC (0005).

Lactifluus gerardii (Peck) Kuntze, Revisio generum plantarum 3 (2): 856. 1891.

Figure 5

The pileus was $30-60 \mathrm{~mm}$ in diameter, flat, depressed in the center and with or without a papilla, moist, rugose velutinose, reddish coffee opaque in the center and clearer towards the margin. Lamellae were decurrent, distant, white, with small veins in some sectors and intervened at the apex in others, with lamellulae of different lengths. The stipe was 30-55 × 8-10 mm, central, cylindrical, with a velutinose surface, and with the same color as the pileus, solid. The context was white, with generous 


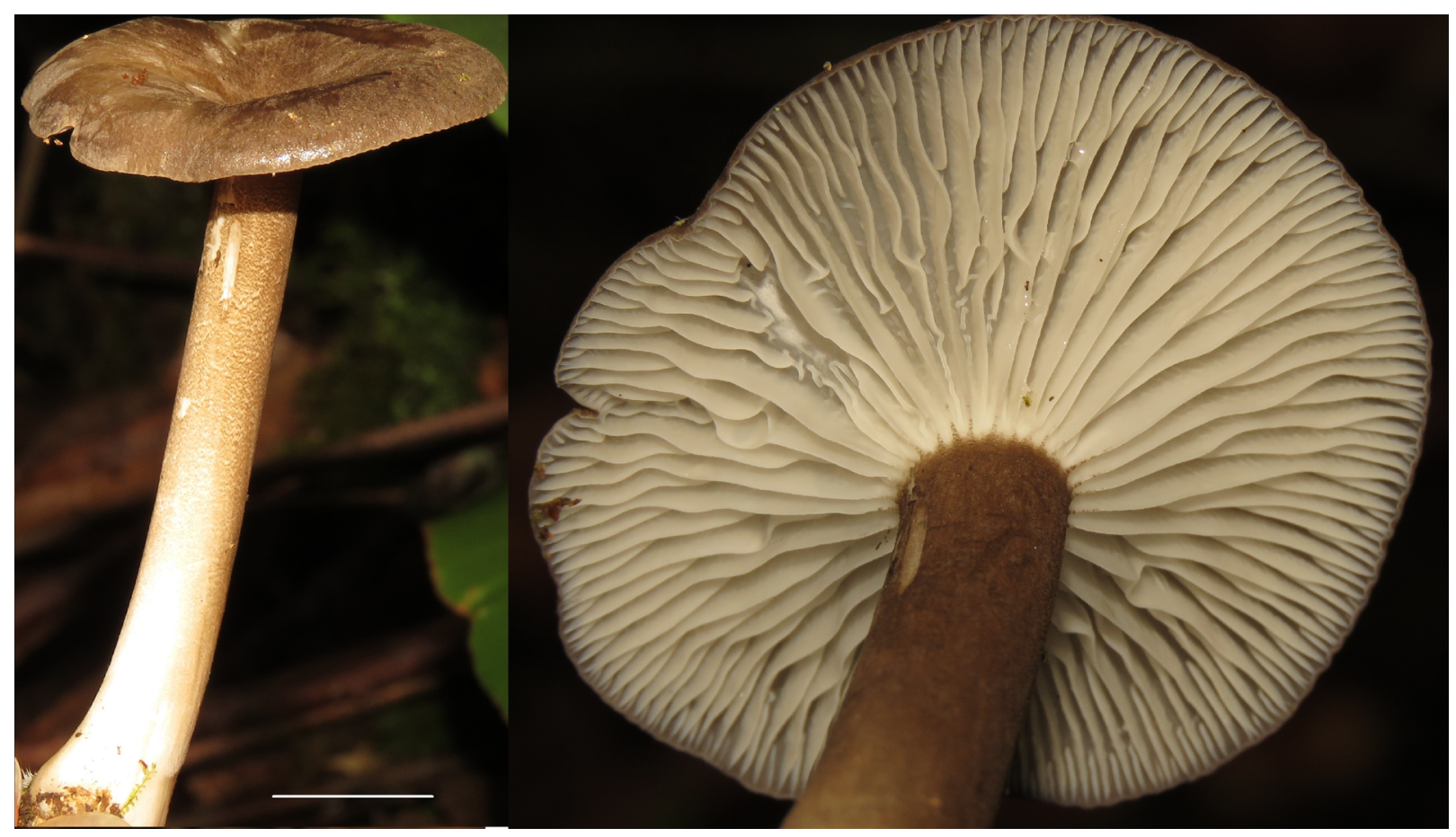

Figure 5. Basidiome of Lactarius gerardii (Peck) Kuntze (Scale $=10 \mathrm{~mm})$.

white latex unchanging on exposure. The spore print was white. The spores were 7-10 × 7.5-9 $\mu \mathrm{m}$, globose to subglobose, with ornamentation up to $0.8 \mu \mathrm{m}$ high, formed by amyloid warts and ridges creating partial or complete reticula. Pleuromacrocystidia were absent, or present as scattered clavate elements slightly projecting. Cheilocystidia were inconspicuous and cylindrical. Cortical layers were formed by a trichoepithelium with long, cystidium-like terminal cells, brown in $\mathrm{KOH}$.

This species grew alone on the ground next to oak trees (Quercus humboldtii). Franco-Molano et al. (2000) and Toro et al. (2011) reported this species to the Department of Antioquia. This is the first citation of L. gerardii in the Boyacá department and the description fits very well with the original diagnosis but needs to be studied by molecular techniques to elucidate its actual taxonomic positioning.

According to Montoya et al. (2012) in the type of L. gerardii var. gerardii the lamellar margin contains basidia (generally bisporic or monosporic) and clavate cells, as observed in our samples. The type collections of Lactarius gerardii var. fagicola and L. gerardii var. subrubescens have clavate cells and some subcylindrical elements on the lamellae edges; these are hyaline, not projecting and not septate. The species was split into several other and some of them were identified only through molecular techniques (Stubbe et al. 2010).

Material examined: COLOMBIA. Boyacá Department, Arcabuco, Reserve of Madre Monte, J. Putzke et al., 13-X-2018, UPTC (0006).

Marasmiellus bolivarianus Singer, Beihefte zur Nova Hedwigia 44: 324. 1973.

\section{Figure 6}

The white pileus was 4-8 $\mathrm{mm}$ in diameter, broadly convex to plano-convex or plane, glabrous to silkyfelted, dry, with striate to sulcate margins and slightly translucent. The lamellae were adnate, white, distant, with brownish edges. The stipe was $1-2 \times 0.5 \mathrm{~mm}$, white, lateral to eccentric, curved, solid, pruinose, with no basal mycelium. The context was very thin, soft and fragile, white, with an odor and taste of garlic or rotten cabbage. The spores were 6.4-8.8 $\times 3.2-4$ $\mu \mathrm{m}$, ellipsoid, thin-walled hyaline and inamyloid. Basidia were 15-21 × 5.6-6.5 $\mu \mathrm{m}$, clavate, tetraspored and fusoid to clavate when young. Pleurocystidia were absent. Cheilocystidia were typically brownish resulting in brown lamellar edges. The pileipellis was a cutis formed by hyphae 4-8 $\mu \mathrm{m}$ in diameter, thin-walled, hyaline to yellowish-white or golden yellow, incrusted, diverticulate, and inamyloid. Clamp connections were present. 


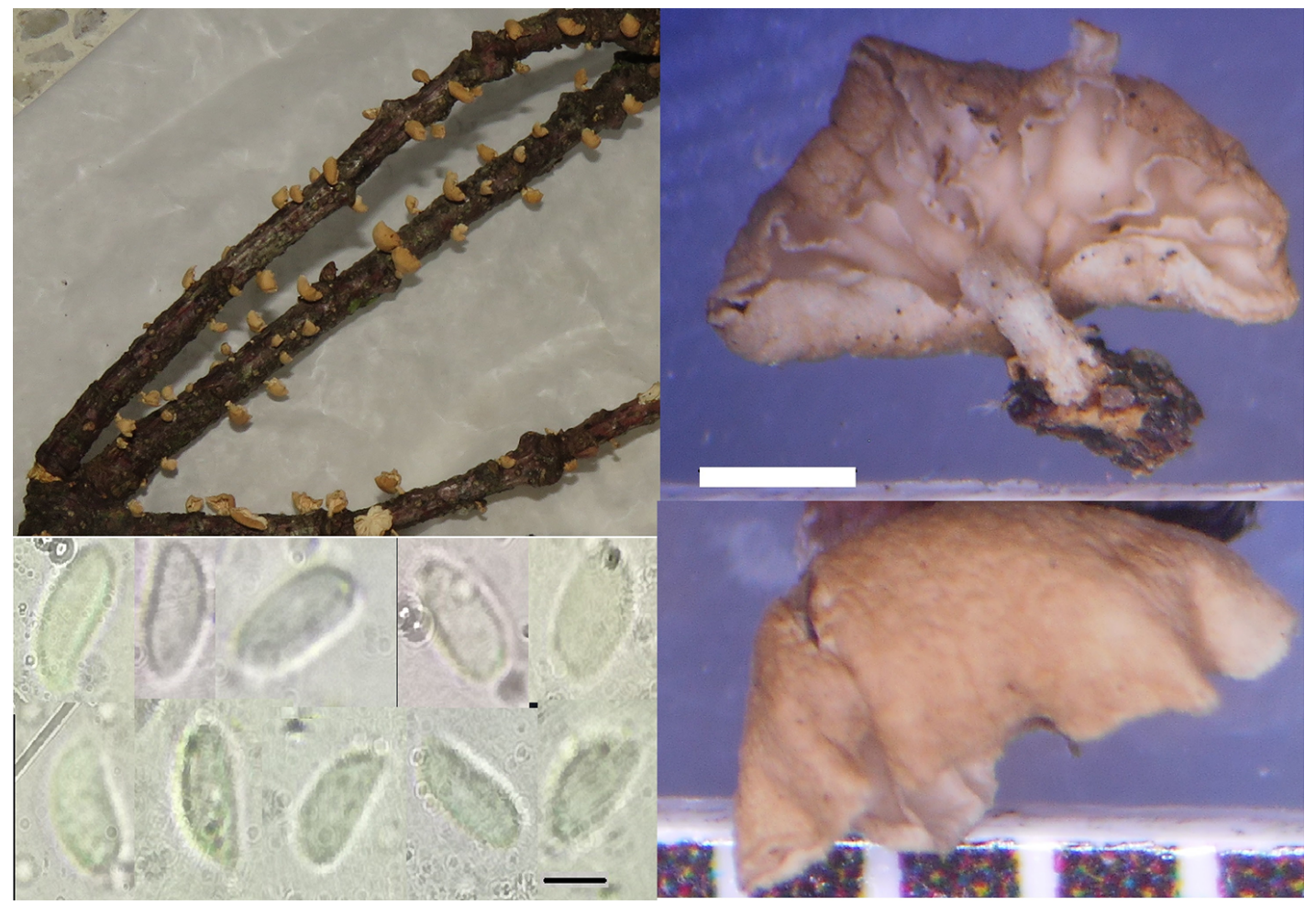

Figura 6. Basidiome and spores of Marasmiellus bolivarianus Singer (Scale: basidiome $=1 \mathrm{~mm}$ and spores $=5 \mu \mathrm{m})$.

This was easily distinguished from other Marasmiellus by the lateral to eccentric stipe and a lamellae edge that was more pallid or brownish with a golden yellowish pigment in the cortical and hypodermial layers. The species was reported originally from Venezuela and recently as aff. to Indonesia (Retnowati 2018) were lamellae edges were found to be paler than the sides (without cheilocystidia). Our sample exactly matched the original one and is the first confirmation of its occurrence outside Venezuela.

This is the first citation of this species in Colombia.

Material examined: COLOMBIA. Boyacá Department, Arcabuco, Reserve of Madre Monte, J. Putzke et al., 13-X-2018, UPTC (0004).

Pluteus chrysophlebius (Berk. \& Curt.) Sacc., Sylloge Fungorum 5: 678. 1887.

Figure 7 a-c

The pileus was $1-2.5 \mathrm{~cm}$ in diameter, broadly conic when young, becoming broadly convex, at times with a central umbo, bright yellow when young, dull yellow or brownish yellow with age, moist, bald, when young sometimes centrally wrinkled or veined, and the margin were sometimes finely lined. Lamellae were free, close or crowded, with frequent lamellulae, whitish at first, becoming pinkish. The stipe was 2050x1-3 mm, equal, fragile, bald, pale yellow, with white basal mycelium. The context was yellowish, with a bleach-like odor when crushed; taste similar, or

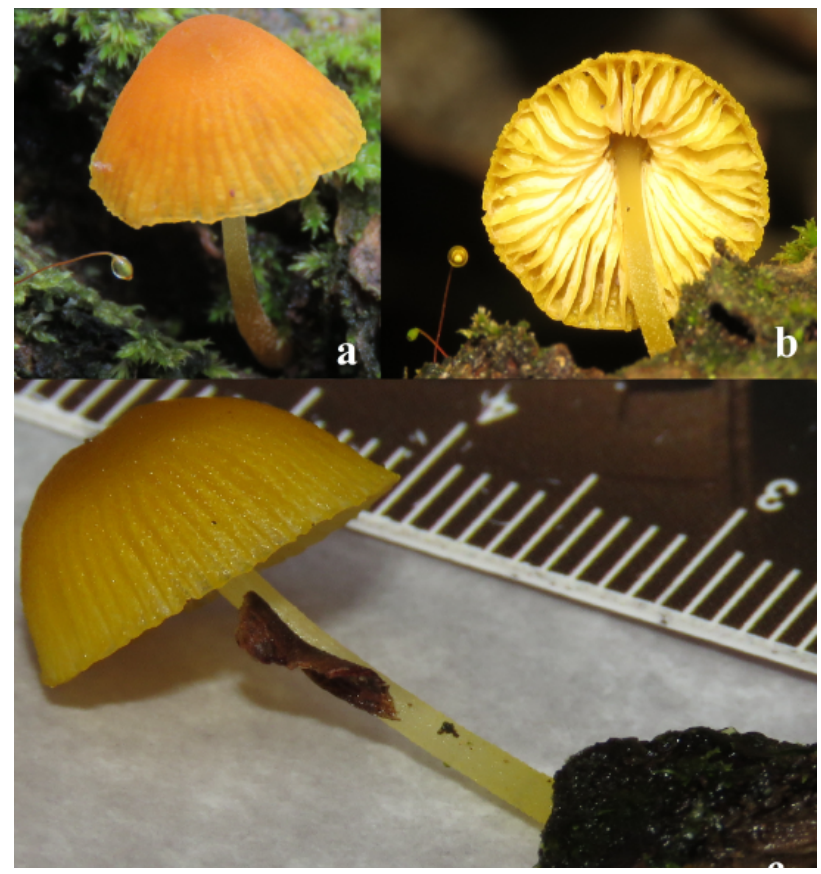

Figure 7 a-c. Basidiome of Pluteus chrysophlebius (Berk. \& Curt.) Sacc. 
not distinctive. The spore print was pink. The spores were 5-7 $\times 4.5-6 \mu \mathrm{m}$, subglobose to widely ellipsoid or sublacrymoid, smooth, hyaline in $\mathrm{KOH}$ and inamyloid. The pleurocystidia were 30-60 × 10-20 $\mu \mathrm{m}$, widely lageniform, with or without an extended neck, thickwalled, and hyaline in $\mathrm{KOH}$. Cheilocystidia were similar to pleurocystidia, or more or less clavate. The pileus cortical layers were hymeniform and hyaline to yellowish in $\mathrm{KOH}$.

This species grew on rotten wood. The golden yellow to strongly yellow pileus and the widely lageniform pleurocystidia and cheilocystidia are typical of this species. Justo et al. (2010) revised American, Asian and European samples, including the original one, using molecular studies and concluded that this is a valid species since many confusions were created by color variations and many synonyms were described. For a list of synonyms see Minnis \& Sundberg (2010).

This is the first occurrence of Pluteus chrysophlebius in Colombia.

Material examined: COLOMBIA. Boyacá Department, Arcabuco, Reserve of Madre Monte, J. Putzke et al., 13-X-2018, UPTC (0008).

\section{Literature cited}

Chacón, S. 1995. Nuevos registros de Agaricales (Fungi) de Mexico. Acta Botánica Mexicana 30: 9-12.

Chardon, C.E. 1928. Contribución al estudio de la Flora Micológica de Colombia. Boletin de la Sociedad Española de Historia Natural 28: 111-124.

Dennis, R.W.G. 1970. Fungus flora of Venezuela and adjacent countries Kew Bulletin Additional Series III. J. Cramer. Vaduz. Londres: Stationery Office Books H.M.S.O.

Dennis, R.W.G. 1986. Fungi of the Hebrides. Royal Botanic Gardens, Kew.

Farook, V.A. \& Manimohan, P. 2014. The genus Campanella (Marasmiaceae, Agaricales): a new species and a new combination and species status. Current Research in Environmental \& Applied Mycology 4: 157-161.

Franco-Molano, A.E., Aldana, R. \& Halling, R. 2000. Setas de Colombia (Agaricales, Boletales y outros hongos). Guía de Campo. Colciencias Universidad de Antioquia, Medellín.

Guzmán, G. 1983. The genus Psilocybe. Beihefte zur Nova Hedwigia Heft 74. Cramer \& Vaduz, Germany.

Halling, R. 1989. A Synopsis of Colombian Boletes. Mycotaxon 44: 93-113.
Henao, L. \& Ruiz, A. 2006. Investigación y Gestión local de robledales alrededor del uso tradicional de macromicetos en la cordillera Oriental colombiana. En: Solano, C. y N. Vargas (ed.). Memorias del I Simposio de Robles y Ecosistemas Asociados. Bogotá. Fundación Natura y Pontifiia Universidad Javeriana.

Horak, E. \& Halling, R. 1991. New records of Phaeocollybia from Colombia. Mycologia 83: 464-472.

Justo, A., Minnis, A.M., Ghignone, S., Menolli, N., Capelari, M., Rodríguez, O., Maslysheva, E., Contu, M. \& Vizzini, A. 2010. Species recognition in Pluteus and Volvopluteus (Pluteaceae, Agaricales): morphology, geography and phylogeny. Mycological Progress 10: 453-479.

López-Quintero, C., Vasco-Palacios, A.M. \& FrancoMolano, A.E. 2007. Macrohongos de un bosque de roble, Quercus humboldtii (Fagaceae). In: NaranjoNarváez G, Toro-Murillo, J.L., Idárraga-Piedrahita, Á., Cardona-Naranjo, F., Pérez-Pareja, S. \& Aguirre-Arias, G.A. (eds.). Reserva Natural Regional Cuchilla Jardín Támesis Antioquia, una mirada a su biodiversidad. Medellín, Colombia. pp. 21-34.

Montoya, F., Arias, D. \& Betancur-Agudelo, M. 2005. Contribución al conocimiento de los hongos Macromicetos del Resguardo Indígena Nuestra Señora de la Candelaria de La Montaña Riosucio, Caldas. Boletín Científico (Centro de Museos) Museo de Historia Natural 9: 19-30.

Montoya, L., Bandala, V.M., Haug, I. \& Stubbe, D. 2012. A new species of Lactarius (subgenus Gerardii) from two relict Fagus grandifolia var. mexicana populations in Mexican montane cloud forests. Mycologia 104: 175-181.

Mueller, G.M. 1992. Systematics of Laccaria (Agaricales) in the continental United States and Canada with discussions of extralimital taxa and descriptions of extant types. Fieldiana Botany 30: 1-158.

Mueller, G.M. \& Vellinga, E.C. 1986. Taxonomic and nomenclatural notes on Laccaria B. and Br., Laccaria amethystea, L. fraterna, L. laccata, L. pumila, and their synonyms. Persoonia 13: 27-43.

Nakasone, K.K., Hibbett, D.S. \& Goranova, G. 2009. Neocampanella, a new corticioid fungal genus, and a note on Dendrothele bispora. Botany 87: 875-882.

Parmasto, E. 1981. On the Asian species of genus Campanella (Tricholomataceae: Collybiae). Nova Hedwigia 34: 437-447.

Pegler, D.N. 1983. Agaric Flora of the Lesser Antilles. Kew Bulletin Add. Ser. IX: 668 pp., 129 fig., 27 pl.

Peña, R.Y. \& Enao, L. 2014. Conocimiento y uso tradicional de hongos silvestres de las comunidades campesinas asociadas a bosques de roble (Quercus humboldtii) en la zona de influencia de la Laguna de Fúquene, Andes Nororientales. Etnobiología 12: 28-40. 
Perera, T.C., Izarduy, C.C., Languasco, M.P. \& Hladki, A.I. 2017. Especímenes Tipo faltantes de la colección histórica de Rolf Singer. Miscelanea 138: 3-12.

Pineda, F., García, G., Velásquez, V. \& Saldarriaga, Y. 1988. Descripción y nuevos registros de Marasmius (Tricholomataceae) en Colombia. Actualidades Biológicas 17: 99-106.

Putzke, J. 2002. Agaricales (Fungos - Basidiomycota) pleurotoides no Rio Grande do Sul. I - Anthracophyllum, Aphyllotus, Campanella, Chaetocalathus e Cheimonophyllum. Caderno de Pesquisa, Série Botânica, 14 45-66.

Rangel, J.O. 2017. Colombia Diversidad Biótica XV. Los bosques de robles (Fagaceae) en Colombia. Composición florística, estructura, diversidad y conservación. Universidad Nacional de Colombia Instituto de Ciencias Naturales, Bogotá D.C.

Retnowati, A. 2018. The species of Marasmiellus (Agaricales: Omphalotaceae) from Java and Bali. Gardens' Bulletin Singapore 70: 191-258.

Segedin, B.P. 1993. Studies in the Agaricales of New Zealand: some new and revised species of Campanella (Tricholomataceae: Collybieae). New Zealand Journal of Botany 31: 375-384.

Singer, R. 1963. Oak mycorrhiza fungi in Colombia. Mycopathologia 20: 239-252.

Singer, R. 1970a. Omphalinae (ClitocybeaeTricholomataceae-Basidiomycetes). Flora Neotropica Monograph 3: 1-84.
Singer, R. 1970b. Phaeocollybia (CortinariaceaeBasidiomycetes). Flora Neotropica Monograph 4: 1-13.

Singer, R. 1975. The Neotropical species of Campanella and Aphyllotus with notes on some species of Marasmiellus. Nova Hedwigia 26: 847-895.

Singer, R. 1976. Marasmiae (BasidiomycetesTricholomataceae). Flora Neotropica Monograph 17: $1-349$.

Singer, R. \& Hausknecht, A. 1990. Some interesting agarics from eastern Austria. Plant Systematics and Evolution 170: 133-150.

Stubbe, D., Nuytinck, J., Verbeken, A. 2010. Critical assessment of the Lactarius gerardii species complex (Russulales). Fungal Biology 114: 271-283.

Toro, J.D.S., González, J.A.A., Sáenz, M.S. 2011. Registro Preliminar de Macrohongos (Ascomycetes y Basidiomycetes) en el Bosque Húmedo Montano del Alto El Romeral (Municipio de Angelópolis, Departamento de Antioquia - Colombia). Revista Facultad Nacional de Agronomía Medellín 64: 1-19.

Vasco-Palácios, A.M. \& Franco-Molano, A.E. 2013. Diversity of Colombian macrofungi (Ascomycota Basidiomycota). Mycotaxon 121: 1-58.

Velásquez, L., Saldarriaga, Y., Pineda, F. \& García, G. 1988. Nuevos registros de hongos en Colombia (departamento de Antioquia) descripción de algunos Agaricales. Actualidades Biológicas 18: 74-94. 